Research Paper

\title{
Seroprevalence of Hepatitis B and C markers at the population level in the municipality of Caxias do Sul, southern Brazil
}

\author{
Débora Menegol, Fernando Rosado Spilki \\ Universidade Feevale, Laboratório de Microbiologia Molecular, Novo Hamburgo, RS, Brazil.
}

Submitted: July 23, 2012; Approved: April 4, 2013.

\begin{abstract}
Chronic viral hepatitis are main public health problems worldwide. Data about the seroprevalence to Hepatitis B and C viruses (HBV e HCV) at the population level are scarce on Brazil and especially for the Southern region of the country. The seroprevalence to HBV and HBC antigens was evaluated on a large portion of the population of the municipality of Caxias do Sul (427,858 inhabitants), Brazil. A total of 60,604 individual serum samples collected from 2008 to 2011 were screened for HBV surface antigen (HBsAg) and for antibodies against HBsAg; anti HCV antibodies were measured by ELISA (Enzyme Linked Immunosorbent Assay). Overall, $1.63 \%$ of the individuals were positive for $\mathrm{HBsAg}$ and $1.43 \%$ showed seropositivity to HCV. From the total, 31,749 samples were analyzed for HBsAg and 28,855 for HCV. For HBsAg, 519 samples showed positive (1.63\%) while the results for 37 patients $(0.12 \%)$ remained inconclusive. For the anti-HCV test, 412 individuals $(1.43 \%)$ showed positive. From the positive samples for HBsAg 216 (50.6\%) were from male individuals whereas for anti-HCV the seroprevalence was slightly higher for females 216 (52.4\%). The higher prevalence for both hepatitis viruses were found among individuals at the age group of 40 to 59 years and the lower levels of positivity for both HBV and $\mathrm{HBC}$ were among children and teenagers.
\end{abstract}

Key words: Hepatitis B virus, Hepatitis C virus, seroprevalence.

\section{Introduction}

Chronic viral hepatitis are considered an important public health problem in Brazil and worldwide. These diseases are caused by different etiological agents, which have in common on its inherent hepatotropism, and many of the clinical laboratory findings. Two etiological agents are most often found, namely Hepatitis B (HBV) and Hepatitis C (HCV) viruses (Ferreira and Silveira, 2004). The World Health Organization (WHO) estimates that 2 billion people have been in contact with HBV, among them more than 350 million may became chronic carriers, while an average of 180 million people are HCV carriers and 130 million may suffer symptoms of the infections (Aquino et al., 2008; Sharma et al., 2005).

The genetic material of HBV (Hepadnaviridae family, Orthohepadnavirus genus) is surrounded by the core and a surface antigen named HBsAg. The presence of detectable antibodies to this protein indicates both acute or chronic infection may be present for more than six months (Lok and McMahon, 2007; Michelin et al., 2007). Transmission occurs by parenteral, sexual or vertical routes; body fluids such as blood, semen and breast milk may contain the virus (Ferreira and Silveira, 2004; Focaccia and Oliveira, 2009). The clinical presentation is highly variable, $30 \%$ of the patients may present the acute icteric form of the disease, while 5 to $10 \%$ may suffer from the chronic hepatitis which may causes cirrhosis and malignant hepatoma (Abbas and Siddiqui, 2011; Anastácio et al., 2008; Lok A and McMahon, 2007; Sharma et al., 2005).

$\mathrm{HCV}$, a member of the Flaviviridae family, Flavivirus genus has a single-stranded RNA genome. An average of $70 \%$ of the infected individuals became chronically infected and $25 \%$ to $30 \%$ of the cases may suffer from cirrhosis after a long period after the primary infection. From $1 \%$ to $4 \%$ of the infected individuals may also develop hepatic carcinoma (Ferreira and Silveira, 2004). Blood transfusion, among others, is accepted as the most

Send correspondence to F.R. Spilki. Laboratório de Microbiologia Molecular, Universidade Feevale, RS-239, 2755, sala 205, $93352-000$ Novo Hamburgo, RS, Brazil. E-mail: fernandors@feevale.br. 
common route of transmission (Ferreira and Silveira, 2004; Focaccia and Oliveira, 2009; Medeiros et al., 2004). The laboratory diagnosis of the infection is performed by the survey of anti-HCV antibodies, which may indicates both acute and chronic infection (Michelin et al., 2007; Ortiz et al., 2006).

Brazilian health authorities estimate that 2 million people are infected by HBV and 3 million are chronically infected by HCV in Brazil (Brasil, 2010). The prevalence in the country varies from low to intermediate depending on the geographic region (Anastácio et al., 2008; Aquino et al., 2008; Bertolini et al., 2012; Brasil, 2010; Souto et al., 2004). In the Southern region of the country, a number of studies showed that although the prevalence of the infection is relatively low, there are some cities in which the prevalence is slightly higher (Bertolini et al., 2012; Ladehof and Bueno, 2005).

There is little information about the seroprevalence to HBV and HCV Caxias do Sul, one of the main cities of state of Rio Grande do Sul, Brazil; the vaccination to HBV is now being widely used in many large municipalities of this geographic region and no studies were made to analyze the impact of vaccination on the seroprevalence of $\mathrm{HBV}$.

The present study was conducted to measure the seroprevalence to $\mathrm{HBsAg}$ and Anti-HCV at the population level on the municipality of Caxias do Sul, one of the largest urban areas of southern Brazil. Variables such as the gender and age group were analyzed.

\section{Materials and Methods}

A cross-sectional study was performed in the period from January 2008 to December 2011, with 60,604 serum samples from patients of public health services included in the databank of a laboratory diagnostic center located in the city of Caxias do Sul (427,858 inhabitants), Rio Grande do Sul, Brazil (Flores and Pereira, 2010). Samples were included by convenience. All the data about the serologic reactions, sex and age were annotated from the data bank of the laboratory, subjects were not identified throughout. The samples were included in the analysis regardless of the clinical history of the individuals. All data from samples with duplication of sample codes or personal identification number were included only once in the final dataset. All ethic and regulatory issues were made under the Brazilian law. Ninety-two percent of population lives on the urban area of the municipality. Life expectancy is 74 years, where the majority of the population is aged 15-64 years, corresponding to $69 \%$. The Caucasian ethnic group represents $88 \%$ of the population. This region has high levels of human development index; however, $7.5 \%$ are considered poor by the Brazilian parameters(Brasil, 2010). HBsAg and Anti-HCV were tested using the Abbott AxSYM System (Abbott ${ }^{\circledR}$, Deerfield, IL, USA) and the ADVIA Centaur HCV screen test (Siemens ${ }^{\circledR}$ Medical Solutions Diagnostics, Los Angeles, CA, USA), respectively, according to the manufac- turer's instructions. Both HBsAg and Anti-HCV results were considered positive (reactive) or negative (non-reactive) according to the interpretation parameters provided by the manufacturers. Since detection of viral nucleic acids was not performed for confirmation of chronic infections, samples in which the serologic results were inconclusive were removed from the final analysis.

The prevalence of each serological parameter was annotated as the percentage of positive samples and the samples of sex and age were compared to these parameters using chi-square test at a $95 \%$ confidence interval in the Statistical Package for Social Sciences version 11.0 (SPSS ${ }^{\circledR}$, Chicago, USA).

\section{Results}

From the total, 31,749 samples were analyzed for HBsAg and 28,855 for HCV. For HBsAg, 519 samples showed positive $(1.63 \%)$ while the results for 37 patients $(0.12 \%)$ remained inconclusive. For the anti-HCV test, 412 individuals (1.43\%) showed positive, and $39(0.13 \%)$ samples were in the grey zone of the analytical test.

From the positive samples for HBsAg, 263 (50.6\%) were from male individuals whereas for anti-HCV the seroprevalence was slightly higher for females $(216,52.4 \%)$. The age group with higher levels of seropositivity was from 40 to 59 years and the lower prevalence was among individuals with less than 19 years of age (Tables 1 and 2). Among male and female on the 40-59 years age group there is a significant difference among genders, $23.5 \%$ and $17 \%$ respectively. In the age group of 30-39 years; however; the opposite happened, more female subjects showed a positive reaction for HBsAg. Seropositivity decreased again after 60 years in the population studied.

\section{Discussion}

The prevalence of viral hepatitis is universal and of variable magnitude according to the study area. There is a higher prevalence in developing countries and societies under poor socioeconomic and sanitary conditions, and also

Table 1 - Prevalence of the serologic marker HBsAg on samples from individuals living at the municipality of Caxias do Sul, Brazil $(n=31,749)$. Data were separated by age group and sex.

\begin{tabular}{|c|c|c|c|c|c|c|}
\hline \multirow{2}{*}{$\begin{array}{l}\text { Age group } \\
\text { (years) }\end{array}$} & \multicolumn{2}{|c|}{ Male } & \multicolumn{2}{|c|}{ Female } & \multicolumn{2}{|c|}{ Total } \\
\hline & $\mathrm{N}$ & $\%$ & $\mathrm{~N}$ & $\%$ & $\mathrm{~N}$ & $\%$ \\
\hline 0 a 10 & 1 & 0.2 & 1 & 0.2 & 2 & 0.4 \\
\hline 11 a 19 & 4 & 0.7 & 7 & 1.3 & 11 & 2.0 \\
\hline 20 a 29 & 14 & 2.7 & 30 & 5.8 & 44 & 8.5 \\
\hline 30 a 39 & 66 & 12.7 & 86 & 16.6 & 152 & 29.3 \\
\hline 40 a 59 & 122 & 23.5 & 88 & 17.0 & 210 & 40.5 \\
\hline$\geq 60$ & 56 & 10.8 & 44 & 8.5 & 100 & 19.3 \\
\hline Total & 263 & 50.6 & 256 & 49.4 & 519 & 100 \\
\hline
\end{tabular}


Table 2 - Prevalence of anti-HCV antibodies on samples from individuals living at the municipality of Caxias do Sul, Brazil $(\mathrm{n}=28,855)$. Data were separated by age group and sex.

\begin{tabular}{|c|c|c|c|c|c|c|}
\hline \multirow{2}{*}{$\begin{array}{l}\text { Age group } \\
\text { (years) }\end{array}$} & \multicolumn{2}{|c|}{ Male } & \multicolumn{2}{|c|}{ Female } & \multicolumn{2}{|c|}{ Total } \\
\hline & $\mathrm{N}$ & $\%$ & $\mathrm{~N}$ & $\%$ & $\mathrm{~N}$ & $\%$ \\
\hline 0 a 10 & 2 & 0.5 & 1 & 0.2 & 3 & 0.7 \\
\hline 11 a 19 & 2 & 0.5 & 1 & 0.2 & 3 & 0.7 \\
\hline 20 a 29 & 5 & 1.2 & 12 & 2.9 & 17 & 4.1 \\
\hline 30 a 39 & 30 & 7.3 & 37 & 9.0 & 67 & 16.3 \\
\hline 40 a 59 & 119 & 28.9 & 98 & 23.8 & 217 & 52.7 \\
\hline$\geq 60$ & 38 & 9.2 & 67 & 16.3 & 105 & 25.5 \\
\hline Total & 196 & 47.6 & 216 & 52.4 & 412 & 100 \\
\hline
\end{tabular}

where vaccination for hepatitis B has not yet been implemented.

Worldwide prevalence of HBV varies from $0.1 \%$ to $30 \%$; there are areas of high endemicity levels (above 7\%), mainly reported in Africa, Southeast Asia, China and Pacific islands, intermediate prevalence (2-7\%), mainly in Eastern Europe and the Mediterranean, parts of Western Europe and Russia. Lower rates of prevalence $(<2 \%)$ are often reported in North America, Western Europe and Australia(Abbas and Siddiqui, 2011; Bertolini et al., 2012; Fonseca, 2010). This may be influenced by several aspects, including the presence of certain viral genotypes, which are also correlated to the ethnic groups living in a given geographic region (Bertolini et al., 2012; Reis et al., 2011).

In Brazil, a heterogeneous country with great diversity of ethnic distribution, economic and cultural differences, it is postulated that there is variation on the prevalence levels for chronic hepatitis (Brazil, 2010). The southern region has a low to intermediate endemicity, with an increasing trend to reach the North, which has the highest percentage of infected individuals in the country (Anastácio et al., 2008; Aquino et al., 2008; Bertolini et al., 2012; Ladehof and Bueno, 2005; Reis et al., 2011). The seroprevalence rates in the country for HBV are ranging from $1.9 \%$ to $13.5 \%$, and the rates found on the present study are slightly below this range, with an overall seropositivity of $1.63 \%$. This may be due to the location where the research was performed, a city with an annual income of US $\$ 16.000$ per capta and the levels of access to both vaccination and health services which are over the national and South American average (Brasil, 2010; Ferreira and Silveira, 2004; Tonial et al., 2011).

Although precise data are scarce on the prevalence of anti-HCV antibodies at population levels, studies based on samples from blood donors showed prevalence rates ranging from $1 \%$ in the United Kingdom and New Zealand to 14\% in Egypt(Ferreira and Silveira, 2004; Fonseca, 2010; Ortiz et al., 2006). Reports suggest a prevalence of $1 \%$ to $2 \%$ in Brazil, the same was observed on this study, in which it was observed a seropositivity of $1.4 \%$ (Ferreira and Silveira, 2004; Tonial et al., 2011).

A low prevalence of $\mathrm{HBV}$ and $\mathrm{HCV}$ was found in infants, children and adolescents on the present study, with rates below $1 \%$, which may be due to the strategies used for prevention of perinatal infection with maternal screening for both hepatitis and especially for hepatitis B vaccination introduced in the basic health services in the region of study during the last decade. Studies have shown that perinatal transmission may be important for the spread of HBV and positivity rates have been increasing in this age group in several regions of the world (Abbas and Siddiqui, 2011).

In a previous Brazilian retrospective study, $61 \%$ of $\mathrm{HCV}$ positive patients were male, differing from the findings of the present study, where occurrence of females was of $52.4 \%$ (Reis et al., 2011). This seropositivity could be attributed to the fact that the population of female attends more regularly to medical services than men, $\mathrm{HCV}$ infection usually runs in a subclinical fashion, showing no symptoms in the early years after contact with the virus, where approximately $70-85 \%$ of patients develop persistent infection and asymptomatic, developing over a long period of time chronic hepatitis, and hepatic cirrhosis(Focaccia and Oliveira, 2010). On the other hand, some women also attend regularly manicures and pedicures, biosafety procedures are often not made properly by these professionals, especially regarding the sterilization of materials used, and this may be an additional route of transmission(Ferreira and Silveira, 2004).

For the HBsAg serologic marker, the male individuals had a slightly higher seropositivity in $50.6 \%$, with a small difference may even represent a sampling bias, which should also take into account that the rates varied according to age of the patients. However, in most studies male presented a higher prevalence, as in a survey of individuals with clinical suspicion of hepatitis, with a rate of seropositivity of $61.1 \%$ for men, revealing that these individuals may be more exposed to the virus because of sexual behavior or even have lower vaccine coverage(Anastácio et al., 2008; Aquino et al., 2008). In one of the only studies conducted in the city of Caxias do Sul, highlights the positive results of serological markers of the blood bank in the period 2001 to 2005, a low prevalence of hepatitis B and C with $0.18 \%$ and $0.12 \%$ respectively, with a higher prevalence in men in both studies. These data have to be taken in account cautiously, since those pre-blood donors are mostly middle aged males, the number of individuals assayed was lower and not restricted to the municipality(Rodriguez et al., 2008).

Both HBV and HCV had a higher prevalence in the age group of patients ranging from 40 to 59 years. Until the year 1992 the anti-HCV assay were not carried out as a screening test for blood transfusions and blood products, and probably at that time this may be main mode of transmission of HCV. Vaccination against HBV in Brazil only 
began in the mid 1990's on children and only later was extended to adolescents and individual on risk groups (Reis $e t$ al., 2011).

\section{Acknowledgments}

FRS is a research fellow from the Brazilian National Council for Scientific Research and Development (CNPq).

\section{References}

Abbas Z and Siddiqui A (2011) Management of hepatitis B in developing countries. World Hepatol 3:292-229.

Anastácio J, Johann A, Silva A, Ruggeri S, Colli C, Panagio, A (2008) Prevalência do vírus da hepatite B em indivíduos da região centro-ocidental do Paraná, Brasil. Ver Soc Biol $3: 10-15$.

Aquino J, Pegado K, Barros L, Machado L (2008) Soroprevalência de infecções por vírus da hepatite $\mathrm{B}$ e vírus da hepatite $\mathrm{C}$ em indivíduos do Estado do Pará. Rev Soc Bras Med Trop 41:334-337.

Bertolini DA, Gomes-Gouvêa MS, Carvalho-Mello IM, Saraceni CP, Sitnik R, Grazziotin FG, Laurindo JP, Fagundes NJ, Carrilho FJ, Pinho JR (2012) Hepatitis B virus genotypes from European origin explains the high endemicity found in some areas from southern Brazil. Infect Genet Evol 12:1295-1304.

Brasil. Ministério da Saúde. Secretaria de Vigilância em Saúde. Departamento de DST, Aids e Hepatites Virais. Boletim Epidemiológico - Hepatites Virais. Ano I, n 1, Brasília; 2010 [on line] [Accessed in 06 dec. 2012]; Available at: www.aids.gov.br/publicacao/boletim-epidemiológico-dashepatites-virais-2010.

Ferreira C and Silveira T (2004). Hepatites virais: aspectos da epidemiologia e prevenção. Rev Bras Epidemiol 7 4:473-487.

Flores AP and Pereira P (2010) Plano Municipal de Assistência Social 2006-2009. Caxias do Sul: Fundação de Assistência Social, 1:7.
Focaccia R and Oliveira A (2009) Prevalência da hepatites B e C em profissionais manicures e pedicures do município de São Paulo. Bepa 6:23-24.

Fonseca J (2010). Histórico das hepatites virais. Rev Soc Bras Med Trop 43:322-330.

Ladehof M and Bueno E (2005) Incidência de hepatites virais em Blumenau-SC, Brasil. Acta Farm Bonaerense 24:436-440.

Lok A and McMahon B (2007) Chronic hepatitis B. Hepatology 45:507-539.

Medeiros M, Lima J, Campos H, Coelho J (2004) Prevalência e fatores associados à hepatite $\mathrm{C}$ em pacientes de hemodiálise. Rev Saúde Pública 38:187-193.

Michelin L, Golin N, Fracasso J, Atti J (2007) Infectologia: Manual de Rotinas. EDUCS. 1:169-185.

Ortiz R, Avellón A, Eiros J (2006) Microbiological diagnosis of viral hepatitis. Enferm Infec Microbiol Clin 24:194-204.

Reis LM, Soares M, França PH, Soares EA, Bonvicino CR (2011) Clonal analysis of hepatitis B viruses among blood donors from Joinville, Brazil: evidence of dual infections, intragenotype recombination and markers of risk for hepatocellular carcinoma. J Med Virol 83: 2103-2112.

Rodriguez D, Lara G, Lazzarotto A, Micheim L, Fracasso J, Lovatel R, Moschem M (2008) Prevalência de marcadores sorológicos no banco de sangue de Caxias do Sul, RS. Rev Panam Infectol 10:32-35.

Sharma SK, Saini N, Chwla Y (2005) Hepatitis B virus: inactive carriers. Virology J 2: 82-86.

Souto F, Fontesi J, Oliveira S, Yonamine F, Santos D, Gaspar A (2004) Prevalência da hepatite $B$ em área rural de município hiperendêmico na Amazônia Mato-grossense: situação epidemiológica. Epidemiol Serv Saúde 13:93-102.

Tonial GC Passos AM, Livramento A, Scaraveli NG, Batschauer AP, Bueno EC, Largura A, Spada C, Treitinger A (2011) Hepatitis B marker seroprevalence and vaccination coverage in adolescents in the City of Itajaí, State of Santa Catarina, Southern Brazil, in 2008. Rev Soc Bras Med Trop 44:416-419.

All the content of the journal, except where otherwise noted, is licensed under a Creative Commons License CC BY-NC. 